\title{
Microbial Culture Preservation With Silica Gel
}

\author{
By A. R. GRIVELL AND J. F. JACKSON \\ Department of Agricultural Biochemistry and Soil Science, \\ Waite Agricultural Research Institute, University of Adelaide, South Australia
}

(Accepted for publication Io July 1969)

Cessation of cellular metabolism is a prerequisite for the preservation and longterm storage of a microbial culture in a state essentially free from the accumulation of morphological and physiological variants (Reusser, 1963). The method of lyophilization (Heckley, 196I) is the most universally used procedure for stock culture preservation.

Hunt, Gourevitch \& Lein (1958) and Perkins (1962) described methods for preserving microbial cultures by dehydration with anhydrous silica gel. The method of Hunt et al., where silica gel and culture are held apart, has been used to preserve fungi (Lange \& Boyd, 1968) and a range of bacterial species (Hunt et al. 1958; Norris, 1963). The technique reported by Perkins, in which a suspension of the micro-organism in skim-milk is added directly to the anhydrous silica gel, has been applied to stocks of the fungi Neurospora crassa, Ustilago maydis, strains of yeast (Perkins, 1962), cystforming slime moulds (Reinhardt, I966) and Claviceps paspali (Mizrahi \& Miller, 1968). This technique is inexpensive, rapid, extremely simple to use and, as reported in this communication, can also be applied to micro-organisms other than fungi.

\section{METHODS}

The experimental procedure used was that described by Perkins (1962) for fungal species. Each of the microbial species tested was grown in the appropriate medium specified in Table I. For Azotobacter vinelandii, the medium contained (g./l. doubledistilled water): sucrose, $10 ; \mathrm{K}_{2} \mathrm{HPO}_{4}, 2 ; \mathrm{MgSO}_{4} \cdot 7 \mathrm{H}_{2} \mathrm{O}, 0.4 ;$ Na-citrate, $0.2 ; \mathrm{NaCl}$, $0.1 ; \mathrm{CaCl}_{2}, 0.05 ; \mathrm{FeSO}_{4} .7 \mathrm{H}_{2} \mathrm{O}, 0.0 \mathrm{I} ; \mathrm{Na}_{2} \mathrm{MoO}_{4} .2 \mathrm{H}_{2} \mathrm{O}, 0.002$; sufficient $\mathrm{HCl}$ to adjust the $\mathrm{pH}$ to $7 \cdot 6 ; \mathrm{NH}_{4} \mathrm{Cl}, 0 \cdot \mathrm{I}$ was added for stock reactivation only. With the exceptions of Aspergillus nidulans and Pseudomonas denitrificans, the organisms were cultured in aerated liquid media and collected by centrifuging at $5000 \mathrm{~g}$ for 5 to 10 min. in sterile plastic centrifuge tubes sealed with screw caps. The cells were resuspended in reconstituted skim-milk ( $15 \%, w / v$; Bonlac obtained from Trufood, Glenormiston, Victoria), previously autoclaved at $\mathrm{I} 2 \mathrm{I}^{\circ}$ for $\mathrm{Io}$ min. A. nidulans conidia and $P$. dinitrificans cells were suspended in milk $(7.5 \%$, w/v) added to cultures growing on agar slopes. It may be that the presence of the skim-milk is a requirement for the successful preservation of bacterial strains by this method (see Hunt et al. 1958; Reinhardt, 1966)

Cotton-wool stoppered $\mathrm{I} 3 \times 100 \mathrm{~mm}$. Pyrex glass tubes were half filled with silica gel (grade as specified by Perkins, 1962) and dry-sterilized at $175^{\circ}$ for 1.5 to $2 \mathrm{hr}$. Pre-cooled suspension $(0.5 \mathrm{ml}$.) was added dropwise to each chilled tube of anhydrous 
silica gel. These were held at $0^{\circ}$ for a further ro to $15 \mathrm{~min}$., then kept for one week in a desiccator containing activated silica gel, prior to a viability test. Finally, each tube was sealed with Parafilm and stored over self-indicating silica gel in a sealed jar at $2^{\circ}$ to $4^{\circ}$.

Reactivation of a dehydrated culture was accomplished by incubating several granules of the silica gel stock in the appropriate liquid medium, the remaining dehydrated material being resealed and stored as described. Thus, each tube of dehydrated culture may be used repeatedly. The medium used to reactivate each culture was the same as that in which it had been grown initially except in the case of Azotobacter vinelandii (above). No estimates were made of relative viabilities.

The metabolic characteristics of the bacteria were tested as described by the following authors: Brownell \& Nicholas (1967) for nitrogen fixation by intact organisms; Radcliffe \& Nicholas (I968) and Lam \& Nicholas (1969) for nitrate and nitrite dissimilation; Adams (1950) for bacteriophage sensitivity.

Table I. Culture conditions and periods of survival of micro-organisms successfully preserved on anhydrous silica gel

\begin{tabular}{|c|c|c|c|}
\hline Species & Strain & $\begin{array}{l}\text { Period of } \\
\text { survival at } \\
\text { last testing } \\
\text { (weeks) }\end{array}$ & $\begin{array}{l}\text { Culture medium } \\
\text { and temperature }\end{array}$ \\
\hline Saccharomyces cerevisiae & DELFT 17 I & 46 & $\begin{array}{l}\text { YEPD medium } \\
\text { (Manney, 1964); } 30^{\circ}\end{array}$ \\
\hline Aspergillus nidulans & bi-I & 37 & $\begin{array}{l}\text { Minimal medium (Cove, } \\
\text { 1966) + I g./1., } \mathrm{KNO}_{3} ; 30^{\circ}\end{array}$ \\
\hline Anabaena cylindrica & - & 107 & $\begin{array}{l}\text { Nitrate medium (Brownell } \\
\text { \& Nicholas, 1967); } \\
25-28^{\circ}\end{array}$ \\
\hline Azotobacter vinelandii & ATCC 13705 & 103 & See text; $30^{\circ}$ \\
\hline Escherichia coli & $\begin{array}{l}\text { B } \\
\text { BB } \\
\text { HS } \\
\text { B-1 } 85 \\
\mathrm{~K}_{12} \lambda \\
830\end{array}$ & $\begin{array}{l}46 \\
45 \\
45 \\
45 \\
66 \\
45\end{array}$ & $\begin{array}{l}\text { Hershey's Nutrient Broth } \\
\text { (Chase \& Doermann, } \\
\text { I958)+0.5 g./l. extra } \\
\text { glucose; } 37^{\circ}\end{array}$ \\
\hline Pseudomonas denitrificans & ATCC 13867 & I I I & $\begin{array}{r}\text { Nutrient agar (Radcliffe } \\
\text { \& Nicholas, I968); } 37^{\circ}\end{array}$ \\
\hline Micrococcus denitrificans & NCIB 8944 & $6 I$ & $\begin{array}{l}\text { Nutrient agar (Radcliffe } \\
\text { \& Nicholas, I968); } 37^{\circ}\end{array}$ \\
\hline Thiobacillus concretivorus & NCIB 9514 & 13 & $\begin{array}{l}\text { Thio-oxidans medium } \\
\text { (Vishniac \& Santer, } \\
\text { I957) with trace elements } \\
\text { diluted ten times; } 30^{\circ}\end{array}$ \\
\hline
\end{tabular}

\section{RESULTS AND DISCUSSION}

Table I lists the microbial species which survived dehydration satisfactorily on anhydrous silica gel, and includes details of the culture conditions. To date, we have been unable to recover viable cells from dehydrated cultures of Thiobacillus thiparus, Chlamydomonas eugametos and Euglena gracilis.

All reactivated cultures had the expected macroscopic and microscopic appearance 
and, when tested, the bacterial strains retained characteristic metabolic properties. Thus, Azotobacter vinelandii intact cells fixed nitrogen gas, Pseudomonas denitrificans and Micrococcus denitrificans dissimilated inorganic nitrogen compounds, Thiobacillus concretivorus lowered the $\mathrm{pH}$ of thiosulphate medium to less than 2, and the several strains of Escherichia coli (excepting the $\mathrm{T}_{4}$-resistant strain, 830 ) were susceptible to infection by bacteriophage $T_{4}$.

This technique of stock culture preservation was particularly useful in simplifying basic microbiological manipulations in an essentially biochemical laboratory. It is recommended for its extreme simplicity and apparent reliability.

The authors thank Professor D. J. D. Nicholas for his interest in this work and Miss Marlene Short for skilled technical assistance. Financial assistance in the form of a CSIRO Postgraduate Studentship to A.R.G. is gratefully acknowledged.

\section{REFERENCES}

Adams, M. H. (1950). Methods of study of bacterial viruses. In Methods in Medical Research. Ed. by J. H. Comroe. Vol. 2, p. I. Chicago: Yearbook Publishers.

Brownell, P. F. \& Nicholas, D. J. D. (1967). Some effects of sodium on nitrate assimilation and $\mathrm{N}_{2}$ fixation in Anabaena cylindrica. Pl. Physiol., Lancaster 42, 915.

Chase, M. \& Doermann, A. H. (1958). High negative interference over short segments of the genetic structure of bacteriophage $\mathrm{T}_{4}$. Genetics, Princeton 43, 332.

Cove, D. J. (1966). The induction and repression of nitrate reductase in the fungus Aspergillus nidulans. Biochim. biophys. Acta $113,5 \mathrm{I}$.

HeCKLEY, R. J. (196I). Preservation of bacteria by lyophilization. Adv. appl. Microbiol. 3, I.

Hunt, G. A., Gourevitch, A. \& LeIN, J. (1958). Preservation of cultures by drying on porcelain beads. J. Bact. 76, 453 .

LAM, Y. \& NicholAS, D. J. D. (1969). Aerobic and anaerobic respiration in Micrococcus denitrificans. Biochim. biophys. Acta r72, 450.

LANGE, B. J. \& BoYD, W. J. R. (1968). Preservation of fungal spores by drying on porcelain beads. Phytopathology 58, 1711.

MANNEY, T. R. (1964). Action of a super-suppressor in yeast in relation to allelic mapping and complementation. Genetics, Princeton 50, I09.

MizraH, A. \& Miller, G. (I968). Long-term preservation of a non-sporulating strain of Claviceps paspali. Appl. Microbiol. 16, I 100.

Norris, D. O. (1963). A porcelain-bead method for storing Rhizobium. Emp. J. exp. Agric. 31, 255.

Perkins, D. D. (1962). Preservation of Neurospora stock cultures with anhydrous silica gel. Can.J. Microbiol. 8, 591 .

Radcliffe, B. C. \& Nicholas, D. J. D. (1968). Some properties of a nitrite reductase from Pseudomonas denitrificans. Biochim. biophys. Acta r53, 545.

ReINHARDT, D. J. (1966). Silica gel as a preserving agent for the cellular slime mold Acrasis rosea. J. Protozool. 13, 225.

REUSSER, F. (1963). Stability and degeneration of microbial cultures on repeated transfer. Adv. appl. Microbiol. 5, 189.

Vishniac, W. \& Santer, M. (I957). The Thiobacilli. Bact. Rev. 21, 195. 